\title{
Peningkatan Prestasi Belajar Baca Tulis Al Qur'an Materi Hukum Bacaan Mad melalui Metode Drill
}

\author{
Suradi \\ SD Negeri Secang 03 Kabupaten Magelang \\ Email: suradi@yahoo.com \\ DOI: 10.18326/mudarrisa.v7i2. 201-228
}

\begin{abstract}
Abstrak
Penelitian ini bertujuan untuk mengetahui apakah metode drill dapat meningkatkan prestasi belajar materi hukum bacaan mad pada siswa kelas V SD Secang 3 Kecamatan Secang Kabupaten Magelang tahun 2012. Penelitian ini merupakan Penelitan Tindakan Kelas. Subjek penelitan adalah seluruh siswa kelas $\mathrm{V}$ yang berjumlah 42 siswa. Pengumpulan data menggunakan dokumentasi dan observasi. Test analisa data menggunakan teknik analisis kuantitatif sekaligus kualitatif. Penelitian ini dilaksanakan dalam tiga siklus dengan langkah-langkah (a) menyusun rencana, (b) pelaksanaan tindakan, (c) observasi dan (d) refleksi. Akhir refleksi pada siklus ketiga menunjukkan bahwa tujuan telah tercapai sehingga penelitian dihentikan pada siklus tiga. Hasil penelitian menunjukkan bahwa metode drill dapat meningkatkan prestasi belajar pada materi hukum mad pada siswa Sekolah Dasar Negeri Secang 3 Kecamatan Secang Kabupaten Magelang tahun 2012. Peningkatan prestasi belajar siswa pada siklus I dengan ketuntasan $74 \%$ dengan ratarata nilai 68,6, siklus II dengan ketuntasan $93 \%$ dengan rata-rata nilai 80, dan siklus III dengan ketuntasan $100 \%$ dengan rata-rata nilai 85 . Penelitian ini bermanfaat untuk guru sebagai masukan agar dapat memperbaiki metode pembelajaran sehingga prestasi belajar siswa kelas V Sekolah Dasar Negeri Secang 3 Kecamatan Secang Kabupaten Magelang tahun 2012 dapat meningkat.
\end{abstract}

This study aims to determine whether the drill method can improve learning achievement of mad materials in class V SD Secang 3 of 
Mudarrisa: Jurnal Kajian Pendidikan Islam, Vol. 7, No. 2, Desember 2015: 201-228

Magelang regency in 2012 or not. It is a Classroom Action Research. The research subjects are all students of class $V$. The data collects by documentation and observation. The data analysis uses both quantitative and qualitative. This research was conducted in three cycles with the steps $(a)$ plan, (b) action, $(c)$ observation and $(d)$ reflection. The end of the reflection in the third cycle indicates that the objective has been achieved so that the study was stopped in three cycles. The results showed that the drill method can improve learning achievement in materials of mad at State Elementary School Secang 3 students. The increase in student achievement in the first cycle with completeness $74 \%$ with an average score of 68.6, the second cycle with completeness $93 \%$ with an average score of 80 , and the third cycle with the completeness of $100 \%$ with an average score of 85 . This research is helpful for teachers as input in order to improve teaching methods so class $V$ student achievement of Secang 3 Public Elementary School can be improved.

Kata kunci: drill, $\mathrm{mad}$, sekolah dasar

\section{Pendahuluan}

Tujuan Pendidikan Nasional yang tertuang dalam UndangUndang Sistem Pendidikan Nasional No. 20 Tahun 2003 tentang Sistem Pendidikan Nasional (Sisdiknas) yaitu mencerdaskan kehidupan bangsa dan mengembangkan manusia Indonesia seutuhnya yaitu manusia yang beriman dan bertaqwa kepada Tuhan Yang Maha Esa, berbudi luhur, memiliki pengetahuan dan keterampilan, kesehatan jasmani dan rohani, kepribadian yang mantap, dan mandiri serta tanggung jawab kepada masyarakat dan bangsa. Untuk mewujudkan tujuan pendidikan nasional, semua pihak harus kerja sama terutama adalah terpusat pada pendidikan baik itu keluarga, sekolah, masyarakat maupun pemerintah.

Perhatian Pemerintah Republik Indonesia terhadap dunia pendidikan begitu besar perhatiannya. Anggaran pendidikan yang 
dialokasikan tiap tahunnya bertambah besar. Pembangunan unit gedung sekolah yang baru, pengangkatan guru baru, pelatihan guru, pemberian bantuan sarana prasarana selalu mengalir. Hal ini dalam rangka untuk meningkatkan mutu pendidikan dan penyelenggaraan pendidikan yang lebih baik.

Pelaksanaan kegiatan belajar mengajar pada umumnya, guru dihadapkan pada dua hal yang harus dicapai yaitu pencapaian tujuan pembelajaran dan ketuntasan belajar siswa. Namun, pada kenyataan hasil yang diharapkan pada pencapaian tersebut kurang memuaskan. Apalagi untuk mata pelajaran pendidikan Agama Islam yang jamnya sangat sedikit dan materi yang harus disampaikan sangat banyak. Sehingga hasilnya sangat jauh dari harapan. Untuk itu upaya-upaya perlu dilakukan agar kesalahan yang dialami siswa dapat dicari pemecahannya. Guru selaku pelaksana langsung di dalam pembelajaran harus berusaha semaksimal mungkin agar siswa-siswa dapat mencapai hasil yang memuaskan. Di samping guru harus kreatif dan inovatif di dalam melaksanakan kegiatan belajar mengajar di kelas. Usaha-usaha tersebut antara lain penggunaan alat peraga, metode yang sesuai, motivasi, dan cara-cara lain yang dapat membuat siswa tertarik dan mudah memahami materi yang diberikan oleh guru.

Kurikulum yang berlaku pada saat ini yaitu Kurikulum Satuan Pendidikan (KTSP) yang merupakan penyempurnaan dari Kurikulum Berbasis Kompetensi (KBK). Dalam kurikulum saat ini, memberi wewenang yang lebih luas kepada sekolah dan guru untuk mengelola pengajaran yang berlangsung di sekolah tersebut. Kerja sama antara guru, 
kepala sekolah, sangat mutlak diperlukan. Pengalaman peneliti selama mengajar di Sekolah Dasar Negeri Secang 3 dalam mata pelajaran Baca Tulis Al Qur'an yang kenyataan ada kesenjangan antara harapan dan kenyataan yaitu nilai yang dicapai siswa sangat rendah yaitu 50 dan tertinggi 75 , sedang untuk ketuntasan yang telah ditetapkan dalam rapat dewan guru dan komite adalah 75. Kesenjangan ini antara lain disebabkan kurangnya jam yang tersedia yaitu dua jam pelajaran per minggu. Metode pembelajaran yang selama ini digunakan kurang efektif dan kurang menarik ini terbukti seringnya siswa kurang memperhatikan dan malah berbicara diluar materi pelajaran. Sebagai solusi peneliti ingin mengadakan Penelitian Tindakan Kelas dengan judul "Peningkatan Hasil Belajar Baca Tulis Al Qur'an Materi Bacaan Mad melalui metode drill'.

Berdasarkan latar belakang masalah yang penulis paparkan di atas permasalahan yang dikaji dalam penelitian ini adalah apakah metode drill dapat meningkatkan hasil belajar siswa pada mata pejaran baca tulis al Qur'an sub pokok bahasan bacaan mad di kelas V SD Negeri Secang 3 Kecamatan Secang Kabupaten Magelang tahun 2012.

\section{Metode Penelitian}

Penelitian yang peneliti lakukan adalah penelitian tindakan kelas atau lebih populer disebut class room action research yaitu bentuk penelitian atau kajian yang bersifat reflektif oleh pelaku tindakan. Tindakan bertujuan untuk meningkatkan atau menetapkan rasional dari tindakan dalam melaksanakan tugas dalam memperdalam pemahaman (Kemmis dalam Saminanto, 2010: 2). 
Alasan peneliti memilih penelitian tindakan kelas adalah untuk memecahkan permasalahan yang ditemukan dalam proses pembelajaran Pendidikan Agama Islam yaitu rendahnya prestasi belajar siswa. Pada akhir tindakan dilakukan refleksi tentang keberhasilan dan kegagalan tindakan terhadap pemecahan masalah. Subyek yang akan digunakan dalam penelitian ini adalah siswa kelas V Sekolah Dasar Negeri Secang 3 Kecamatan Secang Kabupaten Magelang yang berjumlah 42 siswa, terdiri dari 24 putra dan 18 putri.

Penelitian tindakan kelas ini akan peneliti lakukan selama dua bulan yaitu mulai bulan Maret sampai April tahun 2012. Dalam mengumpulkan data peneliti tidak hanya menggunakan satu metode akan tetapi menggunakan beberapa metode, hal ini penulis maksudkan agar data yang terkumpul akan lebih valid. Adapun metode yang peneliti gunakan dalam pengumpulan data adalah metode observasi, metode dokumentasi, dan metode wawancara. Setelah data terkumpul maka perlu dilakukan analisa. Dalam menganalisa data penulis menggunakan teknik analisa data kuantitatif dan analisa data kualitatif.

\section{Pembahasan}

Qur'an merupakan petunjuk dan sumber hukum yang utama dan pertama bagi umat Islam, oleh karena itu mempelajari dan mengajarkan al-Qur'an adalah suatu kewajiban bagi umat Islam, sebagaimanan firman Allah SWT. Dalam al-Qur'an surat al-Taubah ayat 122 berikut:

Tidak sepantasnya bagi orang orang yang mu'min itu pergi semua (kemedan perang). Mengapa tidak pergi dari tiap tiap 
golongan diantara beberapa orang untuk memperdalam pengetahuan mereka tentang agama dan memberi peringatan kepada kaumnya apabila mereka telah kembali kepadanya supaya mereka dapat menjaga diri (Qs. al-Taubah 9:122) .

Juga sabda Nabi Muhammad SAW yang artinya:

Dari Usman bin Affan ra berkata: Rasullullah SAW bersabda : "Orang terbaik diantara kamu adalah yang belajar Al Qur'an dan mengajarkannya"(Makruf Ali, dalam Riyadussalihin 1997:148).

Prestasi belajar ialah hasil yang diperoleh berupa kesan-kesan yang mengakibatkan perubahan dalam diri individu sebagai hasil dari aktivitas dalam belajar (Hamdani, 2011:137), sedang menurut Arikunta (2010: 45) prestasi belajar adalah merupakan hasil yang diperoleh akibat dari kegiatan belajar yang sangat kompleks. Keadaan yang sangat kompleks itu meliputi siswa, guru, dan personal lainnya, bahan pelajaran, metode mengajar, sistim evaluasi, sarana penunjang, dan sistem administrasi. Dua pengertian tersebut dapat ditarik kesimpulan bahwa prestasi dalam bidang pendidikan adalah hasil dari pengukuran terhadap siswa yang meliputi faktor kognitif, afektif, dan psikomotorik. Ketiga faktor tersebut diukur dengan menggunakan instrumen tes atau instrumen lainnya yang relevan. Hasil pengukuran tersebut diwujudkan dalam bentuk angka, kalimat atau huruf. Pada umumnya prestasi belajar diwujudkan dalam bentuk nilai atau raport. Prestasi belajar tidak hanya ditentukan oleh hasil dari kegiatan belajar. Kualitas pembelajaran bukan satu-satunya penentu bagi hasil belajar atau prestasi belajar siswa, akan tetapi prestasi belajar yang mempengaruhi sangat kompleks. Keadaan itu dapat dikelompokkan menjadi empat yaitu, input, output, transformasi, dan 
umpan balik. Input adalah siswa yang memasuki sekolah dinilai kemampuannya untuk mengetahui apakah mampu mengikuti pelajaran atau tidak. Output adalah sejauh mana siswa menyerap pelajaran yang telah diberikan setelah siswa mengikuti pelajaran. Tranformasi adalah mesin yang mengubah input menjadi output. Dalam dunia pendidikan transformasi ini adalah sekolah dan segala yang ada didalamnya. Umpan balik adalah segala informasi yang berkaitan dengan output maupun transformasi. Umpan balik berfungsi memperbaiki output dan transformasi (Arikunta, 2010:5). Faktor yang mempengaruhi belajar sebagai proses atau aktifitas, yaitu faktor dari dalam dan faktor dari luar.

Faktor dari dalam yaitu kecerdasan atau intelegensi yang merupakan kemampuan belajar disertai kecakapan untuk menyesuaikan diri dengan keadaan yang dihadapi (Hamdani, 2011:139). Intelegensi berkaitan dengan potensi diri seseorang untuk berhasil. Semakin tinggi intelegensi seseorang, semakin besar potensi untuk berhasil. Hal tersebut dipengaruhi oleh faktor Fisiologis yang meliputi 2 hal, yaitu kondisi jasmani yang optimal akan lain hasilnya dibanding dengan kondisi yang kurang optimal, yang lelah dan lemah (Suryabrata, 1987:14). Serta keadaan fungsi jasmani tertentu apabila penglihatan dan pendengaran terganggu maka hal ini dapat menghambat subjek belajar (Totok,1988:8).

Sikap yang merupakan kecenderungan untuk mereaksi terhadap suatu hal, orang atau benda dengan suka atau tidak suka, maupun acuh tak acuh. Sikap seseorang dapat dipengaruhi oleh faktor pengetahuan, kebiasaan, dan keyakinan. Siswa harus memiliki sikap positif mampu menggerakkan siswa untuk belajar. Sebaliknya, sikap negatif siswa 
Mudarrisa: Jurnal Kajian Pendidikan Islam, Vol. 7, No. 2, Desember 2015: 201-228

membuatnya tidak mempunyai kemauan untuk belajar (Hamdani, 2011:140).

Minat yang merupakan suatu kecenderungan untuk selalu memperhatikan dan mengingat sesuatu secara terus menerus. Minat berkaitan erat dengan perasaan terutama rasa senang siswa akan sesuatu. Pengaruh minat sangat besar terhadap pembelajaran. Jika siswa senang terhadap sesuatu mata pelajaran, siswa akan belajar dengan senang hati tanpa beban (Hamdani, 2011:140). Minat memiliki pengaruh besar terhadap belajar. Pelajaran yang menarik minat siswa akan mudah dipelajari dan disimpan karena minat menambah kegiatan belajar. Apabila seseorang mempunyai minat yang besar terhadap sesuatu, maka akan terus berusaha untuk melakukan hingga yang diinginkan tercapai.

Bakat merupakan kemampuan potensi yang dimiliki seseorang untuk berhasil. Bakat berkaitan dengan kecakapan. Yaitu kesanggupan tertentu. Tumbuhnya keahlian tertentu pada siswa tergantung pada bakat yang dimiliki. Bakat mempengaruhi tinggi-rendahnya prestasi belajar siswa pada bidang tertentu (Sukmadinata, 2003:102).

Faktor dari luar atau faktor ekstern yaitu faktor yang berasal dari luar siswa dan dapat mempengaruhi hasil belajar. Faktor tersebut antara lain bersumber dari faktor sosial yaitu faktor kehadiran orang lain di saat seseorang sedang belajar yang sering mengganggu jalannya aktivitas belajar. Faktor Non Sosial yaitu faktor yang berasal dari lingkungan sekitar tempat belajar baik dalam bentuk alam seperti cuaca, flora, fauna dan jenis mata pencaharian penduduk, dan alat tulis (Suryabrata,1987:1819). 
Ruang lingkup materi pembelajaran al-Qur'an tingkat dasar berbeda dengan pembelajaran di tingkat menengah. Pada tingkat dasar pembelajaran al-Qur'an terdiri dari dua tingkatan yaitu menghafal surat pendek dan membaca serta menyalin. Secara terperinci bentuk pembelajaran tersebut yaitu mengenal huruf dan tanda baca; membaca kalimat; membaca al-Qur'an dengan tajwid; menyalin huruf, ayat dan surat; menghafal dengan teks dan tanpa teks.

Berdasar materi tersebut dapat dikelompokkan menjadi tiga pola umum yaitu pola umum kegiatan belajar menghafal al-Qur'an untuk surat pendek tanpa teks diberikan untuk kelas 1, 2 dan 3. Langkah-langkah dalam pola tersebut yaitu guru membacakan surat yang harus dihafal secara keseluruhan dengan benar; guru membacakan murid menirukan; guru membacakan per ayat murid menirukan secara kelompok; murid secara kelompok berlatih; murid secara klasikal ikut melafalkan; dan murid diberi pekerjaan rumah untuk memperlancar.

Pola umum kegiatan belajar mengajar membaca al-Qur'an di kelas 4, 5, dan 6. Langkah-langkah untuk tingkatan tersebut yaitu guru membacakan bahan pelajaran secara keseluruhan, murid secara klasikal menirukan; guru membacakan bahan pelajaran bagian-bagian murid menirukan; guru membacakan bagian per bagian murid secara kelompok menirukan; murid yang dipandang mampu membacakan murid secara kelompok menirukan; murid secara kelompok berlatih; masing-masing kelompok memperagakan; dan murid diberi tugas pekerjaan rumah untuk memperlancar bacaan. 
Mudarrisa: Jurnal Kajian Pendidikan Islam, Vol. 7, No. 2, Desember 2015: 201-228

Pola umum belajar mengajar menyalin atau menulis Al Qur'an secara umum yaitu latihan menyalin menulis huruf hijaiyah; latihan menyalin menulis kata dengan huruf lepas; latihan menulis menyalin dengan huruf sambung; dan latihan menyalin menulis kalimat.

Bacaan mad pada garis besarnya terbagi menjadi dua macam yaitu mad thobi'i dan mad far' $i$. Mad thobi' $i$ atau disebut mad asli yaitu memanjangkan bacaan dengan panjang satu alif atau dua harakat. Dibaca Mad Thobi'i apabila terdapat huruf hijaiyah berharokat fatihah bertemu (diikuti) huruf alif; huruf hijaiyah berharokat kasroh bertemu (diikuti) huruf wawu mati; dan Huruf hijaiyah berharokat kasroh bertemu (diikuti) huruf ya' mati.

Mad Far'i yang dalam Bahasa Arab berarti cabang, yaitu cabang dari hukum mad yang asli yang disebabkan oleh hamzah, sukun, waqof, tasydid dan sebagainya yang berfungsi untuk membedakan panjang atau pendeknya bacaan. Adapun mad far' $i$ itu ada tiga belas macam yaitu mad wajib mutasil yang merupakan pemanjangan bacaan dengan panjang bacaan karena ada mad thobi'i bertemu dengan hamzah dalam satu kalimat atau satu kata. Adapun panjang bacaan adalah lima harokat wasol atau terus dan enam harokat apabila waqof atau berhenti. Mad jaiz munfasil mad jaiz memanjangkan bacaan dengan panjang enam harokat. Dibaca mad jaiz munfasil karena ada mad thobi'i bertemu dengan hamzah tidak dalam satu kalimat. Mad 'arid lissukun merupakan pemanjangan bacaan karena adanya mad thob' $i$ bertemu dengan yang dimatikan karena waqof. Adapun panjang bacaan adalah enam harokat. Mad badal adalah pemanjangan bacaan dengan panjang bacaan dua 
harokat atau satu alif. Dibaca mad badal apabila ada mad thobi'i didahului oleh hamzah. Mad iwad yaitu pemanjangan bacaan dua harokat karena harokat tanwin fathah di waqof, kecuali ta' marbutoh karena bila diwaqofkan tetap menjadi ha' mati. Mad lazim mutsaqal kalimi adalah pemanjangan bacaan karena adanya huruf mad bertemu dengan huruf bertasydid dalam satu kalimat. Panjang bacaan adalah enam harokat atau tiga alif.

Mad lazim mukhalaf kalimi yaitu memanjangkan bacaan enam harokat atau tiga alif karena mad badal bertemu dengan huruf mati. Mad lazim harfi musyba' adalah memanjangkan bacaan enam harokat atau tiga alif karena terdapat pada huruf permulaan surah-surah yang bertasydid. Adapun panjang bacaannya ialah enam harokat atau tiga alif. Cara membacanya sesuai dengan huruf asal masing-masing. Mad lazim harfi musyaba' mukhalaf yaitu pemanjangan bacaan yang terdapat pada permulaan surah yang tidak bertasydid, panjang bacaannya adalah dua harokat atau satu alif. Mad Layin merupakan pemanjangan bacaan waqof pada huruf sebelumnya ada wawu mati atau ya' mati, panjang bacaan adalah dua sampai enam harokat. Mad layin ada dua macam, yaitu mad silah kosiroh adalah ha' berharokat domir bertemu selain hamzah, panjang bacaan adalah dua kharokat. Serta mad silah thowilah yaitu sebanyak enam harokat, adanya ha' berkharokat dhomir, dan panjangnya dua kharokat.

Mad farqu yaitu memanjangkan bacaan enam kharokat atau tiga alif. Dibaca mad farqu apabila ada mad thobi'i bertemu dengan huruf yang dimatikan. Mad tamkin yaitu memanjangkan bacaan enam harokat 
Mudarrisa: Jurnal Kajian Pendidikan Islam, Vol. 7, No. 2, Desember 2015: 201-228

atau tiga alif karena ada mad thobi'i bertemu dengan huruf yang bertasydid.

Metode drill yang digunakan sebagai media pembelajaran yaitu mengajar untuk menanamkan kebiasaan-kebiasaan tertentu, juga sebagai sarana untuk memelihara kebiasaan-kebiasaan yang baik. Selain itu metode ini dapat pula digunakan untuk memperoleh suatu ketangkasan, ketepatan, kesempatan, dan keterampilan (Bahri, 2007:242). Metode drill adalah latihan-latihan yang diberikan kepada siswa agar pengetahuan dan kecakapan tertentu dapat dimiliki dan dikuasi sepenuhnya oleh peserta didik (Ismail, 2008:21). Metode ini mengajarkan siswa untuk melaksanakan kegiatan latihan agar siswa memiliki keteguhan atau keterampilan yang lebih tinggi dari pada hal-hal yang telah dipelajari (Hamdani, 2011:273). Langkah-langkah penggunaan metode Drill terdiri dari persiapan yaitu menyediakan peralatan yang diperlukan dan menciptakan kondisi anak untuk belajar. Langkah kedua yaitu pelaksanaan

dengan memberi pengertian atau penjelasan sebelum dimulai, kemudian siswa diberi kesempatan mengadakan latihan (metode drill). Langkah terakhir yaitu evaluasi atau tindak lanjut. Cara kerjanya adalah dengan guru membuat kesimpulan dari latihan yang dilakukan, kemudian guru bertanya kepada siswa dalam bentuk soal latihan (Bahri, 2007:117).

Kelebihan dalam penggunaan metode drill yaitu untuk memperoleh kecakapan motorik, seperti menghafal huruf, kata-kata atau kalimat; untuk memperoleh kecakapan mental, seperti dalam perkalian, penjumlahan, pengurangan dan pembagian; untuk memperoleh 
kecakapan dalam bentuk asosiasi yang dibuat seperti hubungan hurufhuruf dalam ejaan; pembentukan kebiasaan-kebiasaan yang dilakukan dalam menambah ketepatan serta pelaksanaan; pemanfaatan kebiasaankebiasaan yang tidak memerlukan konsentrasi dalam pelaksanaannya; dan pembentukan kebiasaan-kebiasaan membuat gerakan-gerakan yang komplek, rumit menjadi lebih otomatis.

Kelemahan yang terdapat dalam metode drill adalah dapat menghambat bakat inisiatif siswa; menimbulkan penyesuaian secara statis kepada lingkungan. Latihan yang diadakan secara berulang-ulang merupakan hal yang monoton sehingga cenderung membosankan; membuat kebiasaan yang kaku karena bersifat otomatis; serta dapat menimbulkan verbalisme (Bahri, 2007: 108-109).

\section{Pembahasan}

\section{Pelaksanaan penelitian}

\section{Siklus I}

Siklus I penelitian dilaksanakan pada tanggal 8 Mei 2012. Pembelajaran dilaksanakan selama dua jam pelajaran (70 menit) dimulai pada jam 07.15 WIB dan berakhir pada jam 08.25 WIB, adapun materi pembelajaran adalah hukum bacaan mad wajib mutasil dan jaiz munfasil dan dilaksanakan dengan menggunakan metode drill. Tahapantahapannya meliputi perencanaan, pelaksanaan tindakan, observasi, dan refleksi.

Perencanaan diawali dengan identifikasi permasalahan. Permasalahan yang peneliti temukan setelah peneliti melaksanakan 
prasiklus yaitu rendahnya prestasi belajar terutama dalam materi hukum bacaan mad. Sebagai solusi yang peneliti yang peneliti ambil adalah penggunaan metode drill dalam pembelajran materi hukum mad wajib mutasil dan jaiz mufasil. Langkah selanjutnya dalam siklus I adalah membuat RPP sebagai skenario pembelajaran. Guna mendukung lancarnya pembelajaran, langkah selanjudnya yaitu mepersiapkansarana prasarana yang meliputi buku pelajaran, media pembelajaran, alat peraga dan lembar kerja siswa. Instrumen penelitian yang peneliti gunakan meliputi format observasi. Untuk mengamati proses belajar mengajar, dan meminta teman sejawat yaitu Ibu Mafiah, S.Ag sebagai asesmen (Penilai) untuk mengukur hasil belajar.

Pada tahap pelaksaan tindakan sesuai dengan skenario yang peneliti rencanakan yaitu diawali dengan kegiatan pendahuluan. Dalam tahapan tersebut pembelajaran dimulai dengan salam dan doa bersama yang dipimpin ketua kelas. Guru memberi motivasi kepada siswa dengan menjelaskan pentingnya tajwid dalam membaca Al Qur'an. Selanjutnya adalah kegiatan inti berupa penjelaskan materi pembelajaran yaitu hukum bacaan, mad wajib muttasil, dan mad jaiz munfasil dengan menggunakan metode drill . Kemudian siswa diberi waktu untuk bertanya dan guru memberi soal latihan. Tahapan ini diakhiri dengan kegiatan penutup yaitu guru membimbing siswa untuk melakukan refleksi dengan menyimpukan pembelajaran dan mengadakan evaluasi sebagai pengukuran hasil pembelajaran berupa tes tertulis. Guru memberi arahan tindak lanjut berupa pekerjaan rumah. Pembelajaran ditutup dengan doa bersama dan salam. 
Tahapan siklus selanjutnya yaitu observasi yang berupa pengamatan. Tahapan ini dilakukan untuk memgamati situasi kelas, proses belajar mengajar dengan materi mad wajib muttasil dan mad jaiz munfasil, dan juga prestasi belajar siswa apakah sudah mencapai indikator yang ditentukan atau belum. Pengamatan dilakukan oleh rekan guru sebagai penilai yaitu Ibu Mafiyah, SAg. Tahap akhir siklus I yaitu menilai pelaksanaan siklus untuk mengetahui kelebihan dan kekurangan dalam pembelajaran Baca Tulis al-Qur'an materi hukum bacaan mad dengan menggunakan metode drill. Hasil dari refleksi digunakan untuk memperbaiki dan mempersiapkan siklus II, agar indikator yang ditetapkan dapat tercapai.

\section{Siklus II}

Siklus II penelitian dilaksanakan pada tanggal 15 Mei 2012. Pembelajaran dilaksanakan selama dua jam pelajaran (70 menit), dimulai pada jam 07.15 WIB dan berakhir pada jam 08.25 WIB, adapun materi pembelajaran adalah hukum mad arit lisukun, mad badal dan mad iwad dilaksanakan dengan menggunakan metode drill yang disempurnakan. Tahapan-tahapannya meliputi perencanaan pelaksanaan tindakan, observasi, dan refleksi.

Identifikasi permasalahan yang peneliti temukan setelah peneliti melaksanakan siklus II yaitu belum tercapainya kriteria ketuntasan minimal yaitu rata-rata 70 terutama dalam materi hukum bacaan mad. Sebagai solusi yang peneliti ambil adalah penggunaan metode drill yang 
Mudarrisa: Jurnal Kajian Pendidikan Islam, Vol. 7, No. 2, Desember 2015: 201-228

telah disempurnakan dalam pembelajaran materi hukum bacaan mad arid lisukun, mad badal,dan mad iwad.

Langkah selanjutnya dalam siklus II adalah membuat RPP sebagai skenario pembelajaran. Kemudian perlu dilakukan persiapan sarana dan prasarana yaitu meliputi buku pelajaran, media pembelajaran, alat peraga dan lembar kerja siswa. Instrumen penelitian juga perlu dipersiapkan, yaitu meliputi format observasi untuk mengamati proses belajar mengajar, dan meminta rekan kerja yaitu Ibu Mafiah, S.Ag untk menjadi asesmen ( Penilai ) untuk mengukur hasil belajar.

Sesuai dengan skenario yang peneliti rencanakan yaitu diawali dengan kegiatan pendahuluan. Pembelajaran dimulai dengan salam dan do'a bersama yang dipimpin ketua kelas. Guru memberi motivasi kepada siswa dengan menjelaskan pentingnya tajwid dalam membaca al-Qur'an. Dalam kegiatan inti, guru menjelaskan materi pembelajaran yaitu hukum bacaan mad arid lissukud, Mad Badal, dan mad iwad dengan menggunakan metode drill yang telah disempurnakan dan siswa diberi kesempatan untuk bertanya, kemudian guru memberi soal latihan. Kegiatan penutup dilakukan dengan cara guru membimbing siswa untuk melakukan refleksi berupa penyimpulan pembelajaran dan mengadakan evaluasi sebagai pengukuran hasil pembelajaran berupa tes lisan. Kemudian guru memberi arahan tindak lanjut berupa pekerjaan rumah dan pembelajaran ditutup dengan doa bersama serta salam.

Tahap observasi yang berupa pengamatan dilakukan untuk mengamati situasi kelas, proses belajar mengajar dengan materi hukum bacaan mad arid lissukud, mad badal, dan mad iwad, dan juga prestasi 
belajar siswa apakah sudah mencapai indikator yang ditentukan atau belum. Pengamatan dilakukan oleh teman sejawat yaitu Ibu Mafiyah, S.Ag.

Tahap akhir siklus II yaitu dengan merefleksikan pelaksanaan siklus untuk mengetahui kelebihan dan kekurangan dalam pembelajaran Pendidikan Agama Islam dengan materi hukum mad, mad arid lissukud dan mad iwad dengan menggunakan metode drill. Hasil dari refleksi untuk memperbaiki dan mempersiapkan siklus III.

\section{Siklus III}

Siklus III penelitian dilaksanakan pada tanggal 22 Mei 2012. Pembelajaran dilaksanakan selama dua jam pelajaran (70 menit), dimulai pada jam 07.15 WIB dan berakhir pada jam 08.25 WIB. Adapun materi pembelajaran adalah hukum mad lin, mad silah qosiroh, dan mad silah thowilah dilaksanakan dengan menggunakan metode drill.yang telah disempurnakan. Tahapan yang pertama yaitu perencanaan.

Permasalahan yang peneliti temukan setelah peneliti melaksanakan siklus II yaitu masih terdapat siswa yang belum memcapai kreteria ketuntas san minimal terutama dalam materi hukum bacaan mad arid lissukun,mad badal, dan mad iwad. Sebagai solusi yang peneliti ambil adalah penggunaan metode drill yang disempurnakan dalam pembelajaran materi hukum bacaan mad lin, mad silah qosiroh, dan mad silah thowilah. Langkah selanjutnya dalam siklus III adalah membuat RPP sebagai skenario pembelajaran. Guna mendukung lancarnya pembelajaran, lankah selanjutnya yaitu mempersiapkan sarana 
prasaran yang meliputi buku pelajaran, media pembelajaran, alat peraga dan lembar kerja siswa. Instrumen penelitian yang peneliti gunakan meliputi format observasi untuk mengamati proses belajar mengajar, dan meminta teman sejawat yaitu Ibu Mafiah, S.Ag untuk menjadi asesmen (Penilai) untuk mengukur hasil belajar.

Pelaksanaan tindakan diawali dengan kegiatan pendahuluan. Pembelajaran dimulai dengan salam dan doa bersama yang dipimpin ketua kelas. Guru memberi motivasi kepada siswa dengan menjelaskan pentingnya tajwid dalam membaca Al Qur'an. Dalam kegiatan inti guru menjelaskan materi pembelajaran yaitu hukum bacaan mad lin, mad silah qosiroh, dan mad silah thowilah dengan menggunakan metode drill. Kemudian siswa diberi waktu untuk bertanya dan guru memberi soal latihan. Kegiatan penutup dilaksanakan dengan guru membimbing siswa untuk melakukan refleksi berupa menyimpukan pembelajaran dan mengadakan evaluasi sebagai pengukuran hasil pembelajaran berupa tes tertulis. Guru memberi arahan tindak lanjut berupa pekerjaan rumah. Pembelajaran ditutup dengan doa bersama dan salam.

Observasi yang berupa pengamatan dilakukan untuk memgamati situasi kelas, proses belajar mengajar dengan materi hukum bacaan mad arid lisukun,mad badal dan mad iwad, dan juga prestasi belajar siswa apakah sudah mencapai indikator yang ditentukan atau belum. Pengamatan dilakukan oleh teman sejawat yaitu Ibu Mafiyah, S.Ag. Hasil refleksi kegiatan pembelajaran menunjukkan adanya peningkatan prestasi belajar siswa. Situasi siswa menjadi kondusif. Semua siswa mengerjakan tugas dengan baik. 


\section{Hasil Penelitian}

\section{Siklus I}

Dalam proses perencanaan peneliti menentukan materi pembelajaran yaitu hukum bacaan mad, selanjutnya guru membuat rencana pembelajaran (RP) tentang hukum bacaan mad, wajib mutasil, mad jaiz munfasil, selanjutnya membuat alat peraga, yaitu schema/bagan hukum bacaan mad berikut contoh -contohnya pada kertas karton dengan warna yang berbeda-beda, menentukan kriteria yang harus dicapai siswa setelah mengikuti pembelajaran sebagai tolok ukur keberhasilan yaitu siswa dapat membaca dengan benar (dengan bobot nilai 30), dapat membaca dengan fasih (dengan bobot nilai 50 dan dapat membaca dengan lancar (dengan bobot nilai 20). Membuat soal sebagai latihan, membuat lembar kerja siswa siklus I, kemudian meminta guru lain untuk menolong mengamati. Mempersiapkan siswa mengikuti pelajaran dengan membentuk kelompok kecil . Selanjutnya pada soal yang telah ditentukan guru melaksanakan pengajaran dengan menggunakan metode drill dengan alat peraga skema hukum bacaan mad dan tulisan pada karton yang berwarna-warni dengan tulisan AlQur'an yang mengandung bacaan mad dan sebagai metode primer adalah metode drill. Kemudian guru memberikan materi yaitu hukum bacaan mad lengkap dengan tanda bacanya.

Pada mulanya guru menyampaikan secara kelasikal, kemudian siswa dikelompokkan sesuai dengan jumlah anak. Guru membimbing siswa dalam kelompok dan menunjuk anak yang di atas kemampuan rata-rata untuk mendemonstrasikan bacaan dan sekaligus memimpin 
diskusi dalam kelompok. Perwakilan dari masing - masing kelompok maju ke depan untuk mempresentasikan hasil diskusi, dan siswa lain dalam kelompok menanggapi presentasi wakil dari masing-masing kelompok. Pada proses selanjutnya peneliti bekerja sama dengan pengamat lain membantu siswa yang mengalami kesulitan dalam melaksanakan tugas.. Peneliti mengadakan pengamatan terhadap hasil belajar siswa dan memberikan penilaian melalui tes lesan. Materi Penilaian meliputi materi tentang mad wajib mutasil dan jaiz munfasil
1. Mad Wajib Mutasil

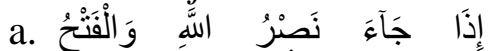

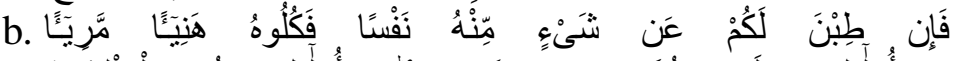

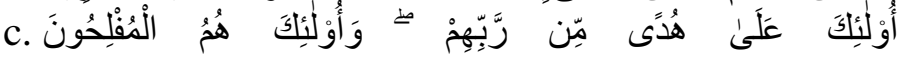

\section{Mad Jaiz Munfasil}

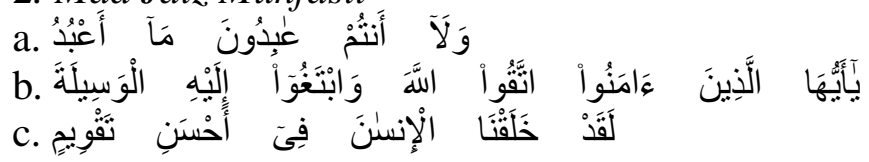

Setelah peneliti bersama Siti Mafiah.S.Ag sebagai pengamat dan penilai mengadakan pengamatan dalam kelas, selanjutnya dilaksanakan refleksi terhadap siswa dalam kegiatan pembelajaran dalam kelompok, ternyata ada kelompok yang dalam diskusi kurang kondusif, scara keseluruhan ada 12 siswa yang tidak mau bertanya, 12 siswa yang tidak mau menjawab dan ada 25 siswa yang kurang bisa kerjasama dalam kelompok, dan 8 siswa yang tidak mau membaca. Hal ini dikarenakan kurang terbiasa antara laki laki dan perempuan dalam satu kelompok, juga masih ada yang kurang berani mengemukakan pendapat, dan ada pula yang ingin mendominasi jalannya diskusi sehingga kurang hidup 
dalam diskusinya. Dalam mengucapkan panjang pendeknya bacaan juga masih ada yang kurang pas. Untuk mengatasi kekurangan pada siklus I selanjutnya langkah yang di tempuh pada siklus II adalah mengintensifkan pembelajaran, membimbing siswa tanpa putus asa dan memotivasi siswa dalam mengikuti pelajaran, dengan baik dan saran dan petunjuk guru serta mengerjakan tugas yang diberikan.

\section{Siklus II}

Pada proses perencanaan peneliti menentukan materi yang akan di sampaikan pada siklus II hukum bacaan mad arid lisukun, mad badal, dan mad iwad. Guru membuat Rencana Pembelajaran yang ada hubungannya dengan materi pembelajaran dan merancang membuat alat peraga yaitu sechama hukum bacaan mad dan membuat alat peraga sekaligus sebagai media pembelajaran, tulisan Al Qur'an yang memuat hukum bacaan mad arid lisukun, mad badal, dan mad iwad. Merancang dan membuat soal-soal latihan untuk dikerjakan dalam bentuk lembar kerja siswa ( L K S ) dan soal-soal latihan serta menentukan tolok ukur keberhasilan yaitu siswa dapat membaca dengan benar nilai 30 dapat membaca dengan fasih bobot nilainya adalah 50 dan membaca dengan lancar bobot nilainya adalah 20. Agar anak lebih kondusif, maka guru selalu memperingatkan kepada siswa untuk lebih serius dalam melaksanakan siklus II. Menentukan jadwal dilaksanakannya siklus II, yaitu Minggu ke dua bulan maret 2012. Pada saat yang telah ditentukan guru melaksanakan pembelajaran dengan alat peraga schema bacaan mad badal, mad iwad, mad lazim musaqol kilmi, dan mad mukhafaf kilmi dan kertas karton yang bertulisan ayat Al Qur'an yang mengandung bacaan 
mad badal, mad iwad, mad lazim musaqol kalimi mad lazim mukhfaf kalimi dan dalam penyampaiannya menggunakan metode driil. Metode drill. guru memberikan beberapa contoh penyelesaian lembar kerja. Pembelajaran disampaikan secara kelasikal seperti penyampaian pada siklus I. Setelah selesai siswa diberi penjelas kemudian diadakan penilaiandengan menggunakan tes lesandenganmateri seagai berikut ;

\section{Mad arid lissukun}

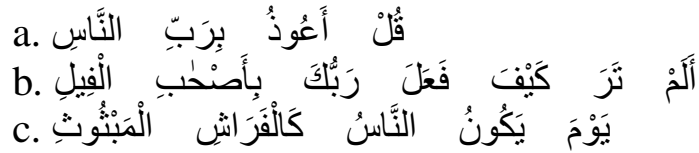

\section{Mad Badal}

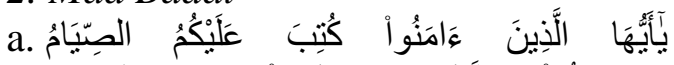

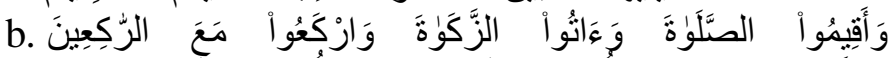

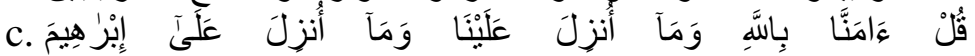

\section{Mad iwad}

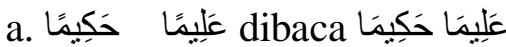

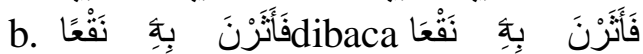

Setelah peneliti mengadakan pengamatan selanjutnya refleksi seluruh pelaksanaan siklus II. Seluruh siswa dalam kelompok telah melaksanakan tugas masing-masing anak telah membawa Al Qur'an, sehingga pelaksanaan kegiatan belajar berjalan tertib dan lancar sesuai dengan yang direncanakan namun demikian masih ada siswa yang pasif dalam diskusi maupun dalam mengerjakan soal, hal ini dapat diatasi dengan memberi motivasi dan arahan secara intensif karena materi termasuk sulit siswa membedakan mad badal dan mad jaiz munfasil. hal ini dapat diatasi dengan mengulang-ulang dan bimbingan guru serta siswa diberi pekerjaan rumah. Kerja sama siswa dalam kelompok cukup 
baik sudah tidak ada yang ingin mendominasi siswa sudah timbul keberanian untuk mengeluarkan pendapat dan untuk menjawab, tutor sebaya pun mulai kelihatan aktif membimbing teman yang kurang menguasai. Pekerjaan siswa belum rapi rata-rata masih banyak coretan. Untuk memantapkan penguasaan materi anak diberi pekerjaan rumah yaitu mencari bacaan, mad wajib munfasil, mad jaiz mutasil, mad arif lisukun, mad badal, mad iwad.

\section{Siklus III}

Pada proses perencanaan peneliti menetapkan materi pada siklus III yaitu hukum bacaan mad lin, madsilah qosiroh, dan mad silah thowilah, selanjutnya guru membuat Rencana Pembelajaran ( RP ) yang berkaitan dengan materi yang telah ditetapkan dan merancang pembelajaran dengan menggunakan metode dril, serta membuat alat peraga dan sekaligus sebagai media pembelajaran disamping Al Qur'an, yaitu scehama hukum bacaan mad yang meliputi mad lin, madsilah qosiroh, dan mad silah thowilah. Dan pembuat soal-soal latihan dalam bentuk lembar kerja siswa (LKS) dan juga soal-soal latihan dan soal test akhir penelitian serta menentukan tolok ukur keberhasilan siswa yaitu yaitu dengan tes lesan dengan materi sebagai berikut.
1.Mad lin

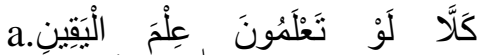

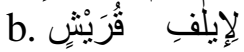
2. Mad silah qosiroh

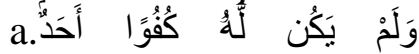
4. Mad silah thowilah 


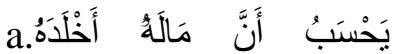

Semua siswa telah melaksanakan tugas masing-masing, sehingga pada pelaksanaan demonstrasi kelompok dapat berlangsung dengan baik dan lancar. Dalam kelompok maupun dalam mengerjakan tugas, di dalam mengerjakan soal-soal latihan (LKS). Kerja sama antar siswa dalam kelompok baik, saling membantu dalam melaksanakan tugas dari guru. Adapun hasil belajar siswa dalam siklus III baik, dengan ketuntasan 100 $\%$ individu.

Berdasarkan hasil refleksi didapatkan antara lain terdapat siswa yang tidak membawa Al Qur'an, sehingga dalam kelompoknya terganggu dan terhambat. Juga terdapat siswa yang canggung hal ini disebabkan karena kurang terbiasa dalam satu kelompok terdiri laki-laki dan perempuan, Juga terdapat anak yang pasif dalam berdiskusi, tetapi ada pula yang over aktif sehingga mendominasi jalannya diskusi bahkan sampai menyeberang kelompok lain. Hal ini bisa diatasi dengan bimbingan guru secara intensif. Masih terdapat siswa yang sulit membedakan antara mad wajib mutasil dan mad wajib munfasil dan juga dalam mengucapkan pendek panjangnya bacaan, dalam mengerjakan siswa masih ada yang tidak mencantumkan sebab dibaca mad, lembar kerja siswa masih banyak coretcoretan sehingga kurang rapi.

Permasalahan yang dijumpai pada siklus I akan diatasi pada pelaksanaan siklus II dan siklus III. Pada pelaksanaan siklus II berjalan dengan baik hasilnya pun ada meningkat, kecanggungan siswa dalam kelompok sudah berkurang siswa mulai terbiasa dengan kerja kelompok , siswa yang over aktif juga sudah tidak ada, siswa yang tidak berani 
bertanya dan mengeluarkan pendapat sudah mulai tumbuh, untuk menjadi relawan dalam membaca pada tiap kelompok sudah banyak yang menunjukkan jari untuk mewakili kelompoknya, tutor sebaya sudah mulai berjalan walaupun disana-sini masih sedikit ada kekurangan. Kesalahan pada pekerjaan siswa yang sering terjadi pada siklus I sudah berkurang yaitu dalam melafalkan sebab dibaca mad, baik mad wajib mutasil maupun mad jaiz munfasil. Semua siswa pada siklus II sudah melaksanakan tugas dari guru seperti untuk membawa Al Qur'an dan mengerjakan pekerjaan rumah sehingga pelajaran menjadi lebih kondusif bila dibanding degan siklus I. Pelaksanaan siklus III berjalan lebih baik, siswa telah terkondisi dengan baik, dalam pengucapan bacaan pendek dan panjang juga sudah dapat membedakannya. Dalam melaksanakan tugas siswa sudah berani membaca, kecanggungan pun juga sudah tidak tampak, siswa juga sudah menyebutkan sebab dibaca mad wajib mutasil, maupun mad jaiz munfasil. Pekerjaan siswa juga sudah tampak rapi coretan-coretan pada kertas pekerjaannya juga sudah tidak tampak lagi.

Ketuntasan belajar pada siklus I mencapai $76 \%$ dengan perolehan nilai rat-rara 68,60, pada siklus II terjadi peningkatan yaitu 93\% dengan perolehan nilai rata-rata 80,dan siklus III 100\% dengan nilai rata 85 Kenaikan ini dipertahankan pada pembelajaran siklus III yaitu dengan perolehan ketuntasan $100 \%$ dan rata-rata nilai 85 . Hal tersebut menunjukkan bahwa pembelajaran dengan metode drill dapat meningkatkan hasil belajar pada pembelajaran membaca Al Qur'an dalam pemahaman hukum bacaan mad dan pengaplikasiannya, hal ini 
diperkuat dengan hasil tes akhir yaitu dengan ketuntasan 100\% dan ratarata nilai 85 .

Dengan demikian hipotesis yang penulis ajukan yaitu "Jika metode drill digunakan dengan baik pada mata pelajara Baca Tulis Al qur'an maka prestasi siswa kelas V SD. Secang 3 Kecamatan Secang Kabupaten Magelang Tahun 2012 dapat diterima"

\section{Kesimpulan}

Hasil penelitian menunjukkan bahwa "Metode Drill dapat meningkatkan prestasi belajar siswa pada mata pelajaran Baca Tulis Al Qur'an materi hukum bacaan mad". Kesimpulan ini diambil berdasarkan pada hasil penelitian yang menunjukkan adanya peningkatan prestasi belajar pada setiap siklus. Hasil penelitian diperoleh peningkatan prestasi belajar siswa dari siklus I dengan nilai rata rata 68,60 (sebesar $76 \%$ ) kesiklus II dengan nilai rata rata 80 (sebesar $93 \%$ ), siklus III nilai rata 85 (sebesar 100\%) dengan demikian terjadi peningkatan dari Siklus I ke Siklus II sebesar adalah $17 \%(93 \%-76 \%)$. sedang peningkatan dari siklus II ke siklus III adalah $7 \%$ ( $100 \%-93 \%)$.

\section{Daftar Pustaka}

Arikunto, Suharsimi. 2002. Dasar-dasar Evaluasi Pendidikan. Jakarta: Bumi Aksara. . 2002. Prosedur Penelitian. Jakarta: Rineka Cipta.

Bahri, Djamarah Syaiful. 2002. Stategi Belajar Mengajar. Jakarta: Rineka Cipta. 
Hamdani. 2011. Strategi Belajar Mengajar. Bandung: Pustaka Setia.

Ismail. 2009. Strategi Pembelajaran Agama Islam. Semarang: RaSAIL Media Group.

Nawawi, Imam. 1999. Terjemahan Riyadhus Shalihin Jilid I. Jakarta: Pustaka

Saminanto. 2010. Mengembangkan RPP PAIKEM, EEK dan BERKARAKTER. Semarang: RaSAIL Media Group.

Santosa, Totok. 1998. Layanan Bimbingan Sekolah Menengah. Semarang: Satya Wacana.

Sukmadinata, Nana Syaodih. 2003. Landasan Psikologi Proses Pendidikan. Bandung: PT. Remaja Rosda Karya.

Suryabrata, Sumadi. 1987. Pengembangan Tes Hasil Belajar. Jakata: Rajawali Press. 
Mudarrisa: Jurnal Kajian Pendidikan Islam, Vol. 7, No. 2, Desember 2015: 201-228 